\title{
(RE)TRANSLATION FROM A PROCESS-ORIENTED APPROACH
}

\author{
Gleiton Malta 1 \\ -1Universidade de Brasília, Brasília, Brazil \\ Cristiane Silva Fontes ${ }^{2}$ \\ ${ }^{2}$ Universidade Federal de Minas Gerais, Belo Horizonte, Brazil \\ Igor A. Lourenço da Silva ${ }^{3}$ \\ ${ }^{3}$ Universidade Federal de Uberlândia, Uberlândia, Brazil
}

\begin{abstract}
This paper reports on a set of three eye-tracking-informed process-oriented studies aimed to tap into the (re)translation task in three different language pairs (Spanish-Portuguese, French-Portuguese, and English-Portuguese). Such studies were built on a task layout demanding potential attention to three textual inputs, namely a source text and two previously published translations thereof, with a view to rendering a fourth text, the new translation. Results point to greater transitions from target text to source text, and vice-versa, as the most frequent flow of visual attention, with occasional shifts to previous translations for solving understanding or production problems in rendering the target text. The results of such studies and the pioneering description of the (re)translation process under experimental conditions may contribute to translation process research by providing some evidence on how participants cope with several inputs in their rendition of a target text.
\end{abstract}

Keywords: Translation process; (Re)translation; Cognitive effort; Eye tracking 


\title{
A (RE)TRADUÇÃO DESDE UMA ABORDAGEM ORIENTADA AO PROCESSO
}

\begin{abstract}
Resumo: O presente artigo reporta um conjunto de três estudos orientados ao processo e baseados em rastreamento ocular, cujo objetivo é explorar a tarefa de (re)tradução em três pares linguísticos diferentes (espanhol-português, francês-português e inglês-português). Estes estudos basearam-se em um design de tarefa exigindo potencial atenção aos três textos que serviram de estímulo, a saber: um texto-fonte e duas traduções previamente publicadas do mesmo, com o objetivo de gerar um quarto texto, uma nova tradução. Os resultados apontam para mais amplas transições do texto-fonte ao texto-meta, e vice-versa, como sendo o fluxo de atenção mais frequente, com ocasionais desvios para as traduções prévias para a solução de problemas de compreensão ou produção durante o ato de produção da tradução. O resultado de tais estudos e a descrição pioneira do processo de (re)tradução sob condições experimentais pode contribuir para a pesquisa do processo tradutório ao franquear evidência de como os participantes lidam com diversos estímulos em sua produção do texto-meta.
\end{abstract}

Palavras-chave: Processo de tradução; (Re)tradução; Esforço cognitivo; Rastreamento ocular

\section{Introduction}

Translation process research has incorporated different data eliciting techniques, such as eye tracking, key logging and screen recording, as a means to tap into expert and novice performance under experimental conditions (i.e. Alves, Pagano \& Da Silva, "A new window", "Toward an investigation"; Jakobsen \& Jensen; Hvelplund, "Allocation", "Eye tracking and the process"; Malta, "O processamento", "O conceito", "El concepto"; O’Brien). Research has commonly focused on translation itself and two related tasks, namely revision and post-editing, to trace the cognitive, the technical and/or the temporal effort involved in each of them, especially when it comes to non-literary texts. However, (re)translation of literary texts - subsequent translations of a source text - remains unexplored within translation process research. 
This paper addresses (re)translation from a process-oriented perspective by reporting on three eye-tracking-informed studies following a research design originally developed by Malta ("O processamento") and replicated by Duarte and Fontes. The objective is to tap into the processing of a task, which, albeit similar to translation at several levels, potentially requires the reading or consulting of at least one previous translation of a source text for the production of a new target text. The understanding of such a process may eventually add to the literature on retranslation, which has usually focused on the translation product (e.g., Dastjerdi \& Mohammadi; Desmidt; Gambier; Malta \& Rael; Malta \& Reis; Paloposki \& Koskinen; Pym; Susam-Sarajeva) to examine the Retranslation Hypothesis (Berman, "La retraduction").

This paper is divided into five sections, including this Introduction. Section 2 contains a review of the literature focused on translation process research, retranslation and eye tracking. Section 3 describes the materials and methods used in the three studies. Section 4 reports the results, focusing on visit and fixation counts and durations as well as on the flow of attention across the textual inputs and the target-text area. Section 5 provides the final remarks.

\section{Review of the literature}

Translation process research has usually centred upon the use of a source text in one language as an input that determines the delivery of a target text (output) in another language (e.g., Carl and Dragsted). In addressing the processes derived from dealing with one target text in the light of the presence or existence of one source text, research has targeted the following tasks in descending order of recurrence: translation (e.g., Alves; Pagano \& Da Silva, "A new window", "Toward an investigation"; Da Silva; Da Silva; Oliveira \& Lima; Jakobsen \& Jensen; Pavlovic \& Jensen), postediting (e.g., Almeida \& O’Brien; Koglin; Krings; O’Brien et al.; Pagano \& Araújo; Sekino), and revision (e.g., Brunnette, Gagnon 


\section{\& Hine; Künzli; Mossop; Robert). Table 1 provides the most common characteristics of such tasks.}

\begin{tabular}{|c|c|c|}
\hline Task & Definition / Structure & Specificities \\
\hline 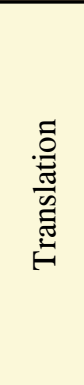 & $\begin{array}{l}\text { Production of a target text } \\
\text { in one language building } \\
\text { on a source text in another } \\
\text { language. } \\
\text { Experimental designs usually } \\
\text { reserve an area of interest } \\
\text { for source text and another } \\
\text { area of interest for target } \\
\text { text on the screen. }\end{array}$ & $\begin{array}{l}\text { - The target text is produced by a human } \\
\text { being, rather than machine translated. } \\
\text { - The translator has access to the source } \\
\text { text. } \\
\text { - Participants include translation } \\
\text { students, translators, and field } \\
\text { specialists. } \\
\text { - Texts are usually non-literary. }\end{array}$ \\
\hline 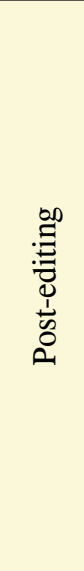 & $\begin{array}{l}\text { Editing of a machine- } \\
\text { translated text. } \\
\text { Experimental designs may } \\
\text { reserve an area of interest } \\
\text { for source text and another } \\
\text { area of interest for target } \\
\text { text on the screen in cases } \\
\text { of bilingual post-editing, or } \\
\text { else they may reserve only } \\
\text { an area of interest for target } \\
\text { text in cases of monolingual } \\
\text { post-editing. }\end{array}$ & $\begin{array}{l}\text { - The target text was machine translated. } \\
\text { - Some tasks constrain participants to } \\
\text { avoid effort and unnecessary changes in } \\
\text { the target text. } \\
\text { - The task should ideally be performed } \\
\text { by a translator. } \\
\text { - The task aims to adjust the machine- } \\
\text { translated text so that it accurately } \\
\text { reflects the target text meaning (Krings, } \\
\text { Mesa-Lao). } \\
\text { - The task can be either bilingual (with } \\
\text { access to the source text) or monolingual } \\
\text { (with no access to the source text). } \\
\text { - Post-editors usually edit texts that were } \\
\text { machine translated into their L1. }\end{array}$ \\
\hline$\frac{\tilde{0}}{\stackrel{0}{0}}$ & $\begin{array}{l}\text { Interferences upon an } \\
\text { original or human translated } \\
\text { text aiming to improve it } \\
\text { at word, phrase and clause } \\
\text { levels. } \\
\text { Experimental designs usually } \\
\text { reserve an area of interest } \\
\text { for the text under revision, } \\
\text { but they may also include } \\
\text { the source text in cases of } \\
\text { translated texts. }\end{array}$ & $\begin{array}{l}\text { - The target text was produced by a } \\
\text { human being. } \\
\text { - It must be performed before delivery of } \\
\text { the text to a client (Robert). } \\
\text { - The task can be performed by a } \\
\text { translator, a reviser, both, or a panel of } \\
\text { professionals. } \\
\text { - The task aims at checking whether } \\
\text { source text and target text matches at } \\
\text { the cultural level or any other level, } \\
\text { looking for potential omissions and } \\
\text { misunderstandings (Krings), and/or }\end{array}$ \\
\hline
\end{tabular}




\begin{tabular}{l|l|l}
\hline \multirow{2}{*}{.0} & $\begin{array}{l}\text { correcting typos and content, form and } \\
\text { punctuation mistakes. } \\
\text { - The task is considered technical, but } \\
\text { not authorial. }\end{array}$ \\
\hline
\end{tabular}

Table 1 - Task types used in translation process research.

Source: Adapted from Malta ("O processamento" 41-42).

Unlike the tasks in Table 1, retranslation requires the acknowledgement (or at least the existence) of at least one previous translation of the source text. In order to account for that, Malta ("O processamento") proposes an eye-tracking experimental design with four areas of interest (cf. Figure 1). Three of such areas would contain potential inputs: the source text in the source language and two previous translations published in different moments in the target language. The remaining area would be reserved for target text production in the target language.

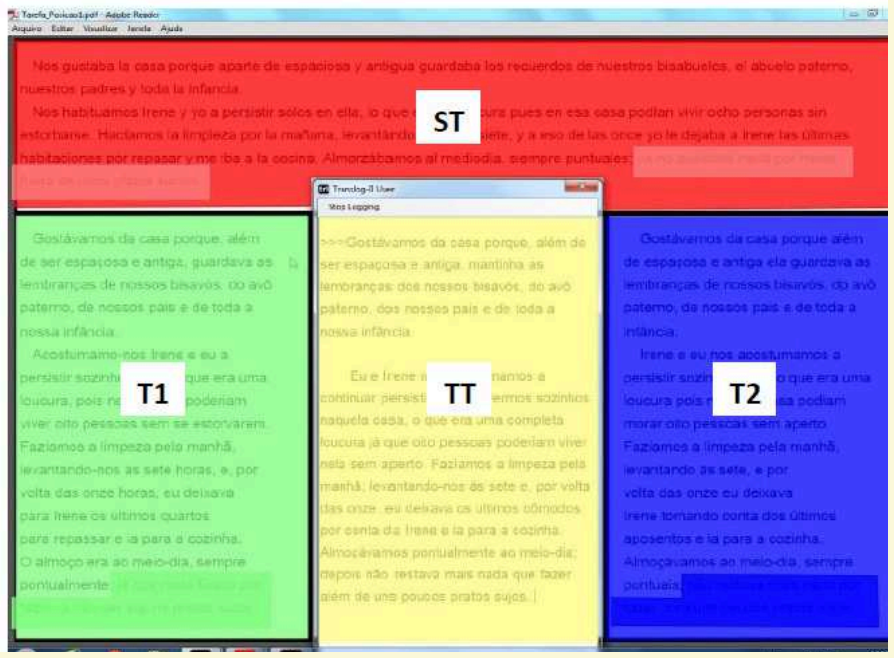

Figure 1 - Experimental layout for a (re)translation task containing input areas of interest for source text (ST), first published translation (T1), and subsequent published translation (T2), and an output area for target text production (TT).

Source: Malta (“O processamento" 59). Note: T1 and T2 positions are interchangeable. 
The experimental layout in Figure 1 was based on Berman's ("La retraduction") hypothesis that retranslations are at an advantage to the first translations: retranslations can come closer to the original because they can both instantiate features from the source text that were missing in the translations and reuse previous instantiations that were successful in such translations. According to this hypothesis, the first translation of a literary text is an "incomplete" act because it "deforms" the original to make it fit for the target culture, and "completeness" can only be attained or searched for by means of retranslation and increasing familiarization of the target culture with the source culture over time (i.e., "time effect") (e.g., Berman, "La retraduction", "A tradução"; Bensimon; Gambier; Chesterman).

More precisely, the design was intentionally based on the historyas-progress model: new translations aim to recover features of the original that were lost in the first translation(s) (Gambier). Such a model has been disproven in numerous cases (e.g., Paloposki \& Koskinen; Susam-Sarajeva; Brownlie; Deane-Cox), but it was chosen as a starting point precisely because of its falsifiable nature. $\mathrm{T} 1$ and $\mathrm{T} 2$ positions are interchangeable, and participants are not aware of which translation was published first, so they can choose from any, if at all, to either "influence" their target text, to crossreference their work or even to ensure their authorial differences from preceding versions (cf. Venuti). In fact, this design seemed to be useful because it accounts for a continuum from participants who may try to avoid some "anxiety of influence" (Bloom) to participants who may be mere copyists of a supposedly "good enough" translation. It only fails to account for cases in which retranslators are unaware of previous translations or do not have access to them because they are out of print, for example.

Upon proposing such a design and testing it, Malta ("O processamento" 190) defined (re)translation as a task whereby the translator deals with a source text whose previous translation(s) into the target language $\mathrm{s} / \mathrm{he}$ is aware of and $\mathrm{s} / \mathrm{he}$ can use as input(s) in the production of his/her new target text. The author 
uses the term (re)translation as specific from a process-oriented perspective, as opposed to retranslation, which is commonly used in product-oriented approaches. The prefix $r e$ - within brackets indicates that the translator may be aware of the previous translations and even recall them or access one or more of them to merely copy one of them, make some tweaks in one of them, get some inspiration from one, some or all of them, or to ensure authorial differences from some or all of them, but $\mathrm{s} /$ he may well produce his/her target text from scratch, in a process quite similar to that usually referred to as translation.

\section{Methodology}

Malta ("O processamento"), Duarte and Fontes used the experimental layout displayed in Figure 1. They are part of a larger project aimed at describing (re)translation by means of processoriented research.

Table 2 shows the participants and language pairs used in the aforementioned studies. They elicited data through eye tracking, key logging and retrospective verbal protocols, but this paper is limited to the eye-tracking data.

\begin{tabular}{l|l|l|l}
\hline Study & Participants recruited & $\begin{array}{l}\text { Remaining } \\
\text { participants } \\
\text { upon data } \\
\text { quality } \\
\text { assessment }\end{array}$ & Language pair \\
\hline Malta & $\begin{array}{l}\text { 31 Brazilian teachers } \\
\text { of Spanish } \\
\text { 31 Brazilian } \\
\text { undergraduate } \\
\text { students of } \\
\text { Translation in } \\
\text { Spanish-Portuguese }\end{array}$ & $\begin{array}{l}4 \text { teachers } \\
10 \text { students }\end{array}$ & Spanish > Portuguese \\
\hline
\end{tabular}

Cad. Trad., Florianópolis, v. 39, nº 1, p. 191-215, jan-abr, 2019. 


\begin{tabular}{l|l|l|l}
\hline Duarte & $\begin{array}{l}12 \text { Brazilian } \\
\text { undergraduate } \\
\text { students of } \\
\text { Languages, with } \\
\text { proficiency in French }\end{array}$ & 11 students & French > Portuguese \\
\hline Fontes & $\begin{array}{l}16 \text { Brazilian } \\
\text { undergraduate } \\
\text { students of English } \\
\text { Language } \\
11 \text { professional } \\
\text { translators }\end{array}$ & 5 students \\
\hline
\end{tabular}

Table 2 - (Re)translation studies: participants and language pairs.

The three studies recruited 101 participants overall. However, data from only 35 participants remained after the application of three eye-tracking data quality criteria, namely: 1) average fixation duration, 2) gaze time on screen, 3) gaze sample to fixation percentage (Hvelplund, "Eye tracking and the translation process"). Such criteria were used to ensure that data were reliable and accounted for the entire process, since eye-tracking data may be partially or completely lost due to several factors, including changes in lighting conditions and participants' abrupt head moves.

Eye tracking was used because it elicits data that are indicative of cognitive effort and data that cannot be directly observable in the translation product or even in the translation process, especially when the translator is reading a text (Pavlović \& Jensen). The use of eye tracking builds on the eye-mind assumption, which holds that what any individual is fixating on is what $\mathrm{s} / \mathrm{he}$ is processing cognitively (Just \& Carpenter).

More specifically, this paper addresses the following eyetracking variables: fixations and visits into the areas of interest. Fixation refers to the relatively stationary maintaining of the visual gaze on a single location for at least 200 to 350 milliseconds (Rainer \& Pollatzec). According to Malta ("O processamento"), visit refers to the access to a given area of interest for visual gaze 
on it; in translation process research, visits may inform on how often a participant moves from an area of interest, such as the source text, to another, such as the target text, and vice-versa.

In order to elicit data, Malta ("O processamento"), Duarte and Fontes selected texts in Spanish, French and English, respectively, by using the following criteria: 1) the source text is an excerpt from a literary work originally written in the participants' L2, the choice for a literary text being based on the recurrence of retranslations of this text type (Tahir-Gürçalar 233); 2) the time lapse between the first published translation in Brazilian Portuguese and its retranslation is important to account for the time effect suggested by the retranslation hypothesis (Berman, "La retraduction"); and 3) the source-text and the (re)translated excerpts contain at most 110 words (cf. Table 3), so that the task could be performed without fatigue and other intervening factors.

\begin{tabular}{l|l|l|l}
\hline Study & Source Text & Translation 1 & $\begin{array}{l}\text { Translation 2 } \\
\text { (retranslation) }\end{array}$ \\
\hline Malta & $\begin{array}{l}\text { Casa Tomada, by } \\
\text { Cortázar (1946) } \\
\text { Spanish } \\
98 \text { words }\end{array}$ & $\begin{array}{l}\text { Alicia Ramal } \\
(2005) \\
99 \text { words }\end{array}$ & $\begin{array}{l}\text { Heloísa Jahn } \\
(2013) \\
92 \text { words }\end{array}$ \\
\hline Duarte & $\begin{array}{l}\text { L'amant, by } \\
\text { Marguerite Duras } \\
(1984)\end{array}$ & $\begin{array}{l}\text { Aulyde Soares } \\
\text { Rodrigues } \\
(1985)\end{array}$ & $\begin{array}{l}\text { Denise Bottmann } \\
(2007)\end{array}$ \\
& $\begin{array}{l}\text { French } \\
106 \text { words }\end{array}$ & \\
\hline Fontes & $\begin{array}{l}\text { Emma, by Jane } \\
\text { Austen (1815) }\end{array}$ & $\begin{array}{l}\text { Ivo Barroso } \\
(1996)\end{array}$ & $\begin{array}{l}\text { Doris Goettems } \\
(2011) \\
96 \text { words }\end{array}$ \\
& $\begin{array}{l}\text { English } \\
91 \text { words }\end{array}$ & words & \\
\hline
\end{tabular}

Table 3 - Source texts and their translations and retranslations into Brazilian Portuguese. 
The experiments were carried out in three stages, following Jakobsen's (15-16) suggestions.

Stage 1 was a warm-up session, which was designed for the participants to get familiar with the equipment and the screen layout as shown in Figure 1. In this stage, following the layout in Figure 1 , the participants were instructed to choose one of the three texts available on the screen (ST, T1, or T2) and copy it to the central area (TT in Figure 1).

Stage 2 was the experiment itself, whereby the participants were asked to translate the ST into Brazilian Portuguese for publication purposes. They could do so either from scratch without any support of the previous translations or by consulting any of or both previous translations provided. The experiment was carried out without any time constraint and any external support apart from the previous translations.

Stage 3 involved a free recall protocol, whereby the participants were asked to tell everything they could remember from their retranslation process while watching a recording of their process sped up in 500\%. These data are not analysed in this article.

The data were statistically tested using paired Student's t-tests for parametric data and Wilcoxon's test for non-parametric data, both with significance set at $\mathrm{p} \leq 0.05$. The Student's t-tests assessed differences in mean, while the Wilcoxon's tests assessed differences in mean ranks.

\section{Results}

In Malta's ("O processamento"), Duarte's and Fontes's studies, the results point to prevailing visual attention in the TT and ST areas of interest, with previous translations playing a secondary role in the task. Figure 2 confirms this result with an example from Malta's research: the heat map in image 'a' shows hotter colours, meaning a higher number of fixations in the top screen area and in the middle screen area, while the gaze plot 
in image ' $b$ ' displays a higher count of fixations (represented through circles) in these two areas. In contrast, both right and left screen areas had a lower count of fixations, as represented by both green or transparent colours in image ' $a$ ' and lower number of circles in image 'b.'

a)

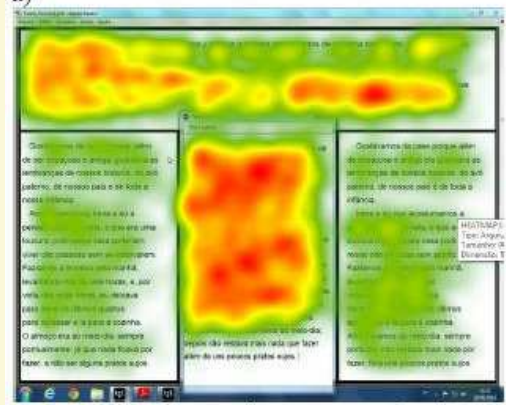

b)

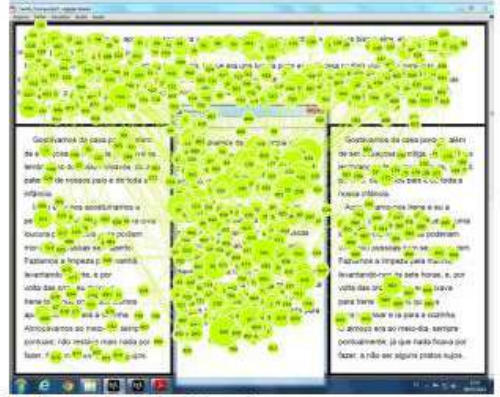

Figure 2 - Heat map and gaze plot of the participants' (re)translation process. Source: Malta ("O processamento", 300).

Overall, Malta, Duarte and Fontes found 2,789, 1,431, and 3,104 visits, and 15,559, 25,145, and 18,662 fixations, respectively (cf. Figure 3 ). The overall number of visits and fixations do not seem to be directly related to the number of participants - 14 in Malta, 11 in Duarte, and 10 in Fontes and may be indicative of an influence of participants' profile and language pairs. However, further research is needed in order to evince such influence. 


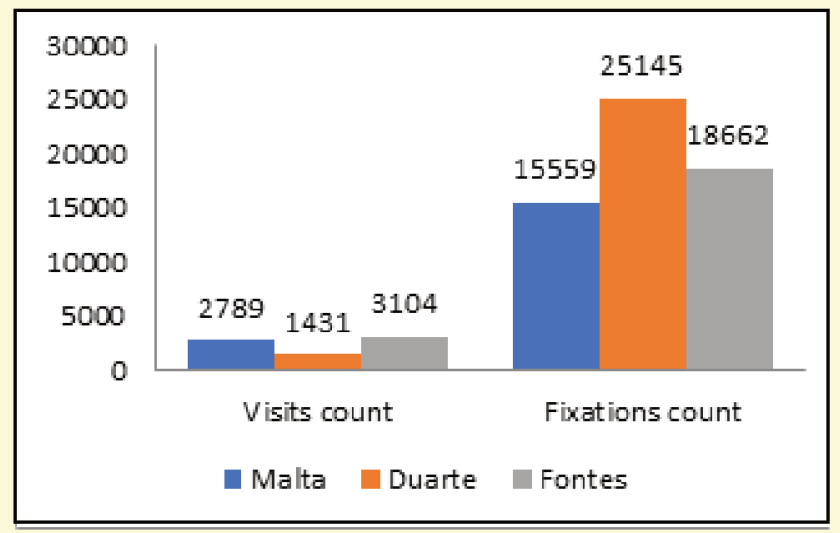

Figure 3 - Fixation count and visit count in Malta, Duarte and Fontes.

Still, the three studies point to a potential default behaviour across participants regardless of language pair: TT and ST areas are the most visited and fixated areas, while previous translations seem to play an ancillary role, as shown in and discussed for Figures 4 to 6.
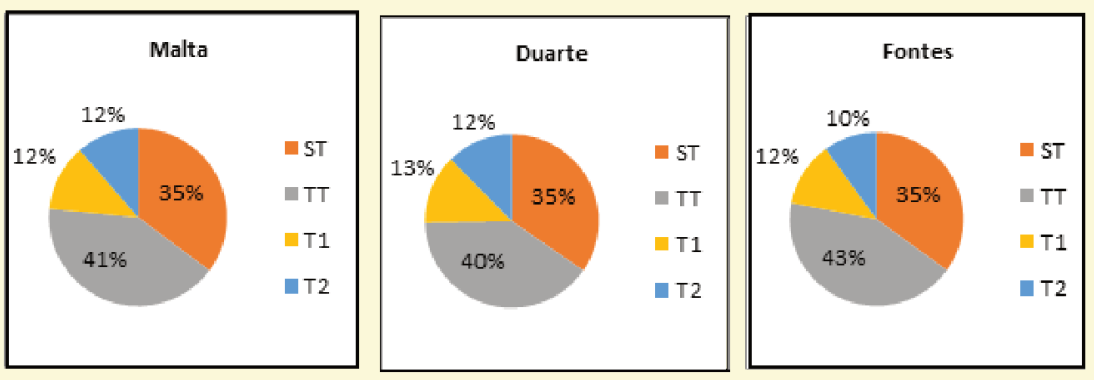

Figure 4 - Visits into the areas of interest in Malta, Duarte and Fontes.

The differences between the areas of interest are significant for visit counts in both Malta and Duarte, especially when it comes to the eye movements from ST to TT and from those areas of interest to the previous translation, and vice-versa (cf. Table 4). 
The small, albeit insignificant, difference between the two studies may be related to participant profiles and language pair.

Differences are also found for fixation counts when it comes to eye movements from ST and TT to the previous translations. However, no significance was found in eye movements from ST to TT and from $\mathrm{T} 1$ to $\mathrm{T} 2$, and vice-versa, in both studies (cf. Table 4).

\begin{tabular}{|c|c|c|c|c|c|}
\hline \multirow{2}{*}{ Study } & \multirow{2}{*}{$\begin{array}{l}\text { Combi- } \\
\text { nations }\end{array}$} & \multicolumn{2}{|l|}{ VISIT COUNT } & \multicolumn{2}{|c|}{ FIXATION COUNT } \\
\hline & & Results & Relation & Results & Relation \\
\hline Malta & $\begin{array}{l}\text { ST-T1 } \\
\text { ST-T2 } \\
\text { TT-ST } \\
\text { TT-T1 } \\
\text { TT-T2 } \\
\text { T1-T2 }\end{array}$ & $\begin{array}{l}p=0.01571 \\
p=0.01365 \\
p=0.00198 \\
p= \\
0.000000876 \\
p=0.0006063 \\
p=0.58047 \\
\text { (ns) }\end{array}$ & $\begin{array}{l}\mathrm{ST}>\mathrm{T} 1 \\
\mathrm{ST}>\mathrm{T} 2 \\
\mathrm{TT}>\mathrm{ST} \\
\mathrm{TT}>\mathrm{T} 1 \\
\mathrm{TT}>\mathrm{T} 2 \\
\mathrm{~T} 1>\mathrm{T} 2\end{array}$ & $\begin{array}{l}p=0.000009583 \\
p=0.000004587 \\
p=0.43631(\mathrm{~ns}) \\
p=0.0001221 \\
p=0.0001221 \\
p=0.33473(\mathrm{~ns})\end{array}$ & $\begin{array}{l}\mathrm{ST}>\mathrm{T} 1 \\
\mathrm{ST}>\mathrm{T} 2 \\
\mathrm{TT}<\mathrm{ST} \\
\mathrm{TT}>\mathrm{T} 1 \\
\mathrm{TT}>\mathrm{T} 2 \\
\mathrm{~T} 1<\mathrm{T} 2\end{array}$ \\
\hline Duarte & $\begin{array}{l}\text { ST-T1 } \\
\text { ST-T2 } \\
\text { TT-ST } \\
\text { TT-T1 } \\
\text { TT-T2 } \\
\text { T1-T2 }\end{array}$ & $\begin{array}{l}\mathrm{p}=9.554 \mathrm{e}-06 \\
p=3.288 \mathrm{e}-07 \\
p=0.0008441 \\
p=1.395 \mathrm{e}-05 \\
p=2.261 \mathrm{e}-06 \\
p=0.6831(\mathrm{~ns})\end{array}$ & $\begin{array}{l}\mathrm{ST}> \\
\mathrm{T} 1 \\
\mathrm{ST}> \\
\mathrm{T} 2 \\
\mathrm{TT}> \\
\mathrm{ST} \\
\mathrm{TT}> \\
\mathrm{T} 1 \\
\mathrm{TT}> \\
\mathrm{T} 2 \\
\mathrm{~T} 1> \\
\mathrm{T} 2\end{array}$ & $\begin{array}{l}p=0.0009766 \\
p=0.0001189 \\
p=0.6495(\mathrm{~ns}) \\
p=0.0009766 \\
p=2.213 \mathrm{e}-05 \\
p=0.8984(\mathrm{~ns})\end{array}$ & $\begin{array}{l}\text { ST }> \\
\text { T1 } \\
\text { ST }> \\
\text { T2 } \\
\text { ST }>\text { TT } \\
\text { TT }> \\
\text { T1 } \\
\text { TT }> \\
\text { T1 } \\
\text { T2 }> \\
\text { T1 }\end{array}$ \\
\hline
\end{tabular}

Table 4 - Significance test results for visit and fixation counts in Malta and Duarte. Note: $\mathrm{ns}=$ non-significance $(\mathrm{p}>0.05)$.

Like visit and fixation counts, visit and fixation durations were also longer in the ST-TT combination. Durations were higher in the TT area, followed in this order by the ST and the previous translations (cf. Figure 5). 


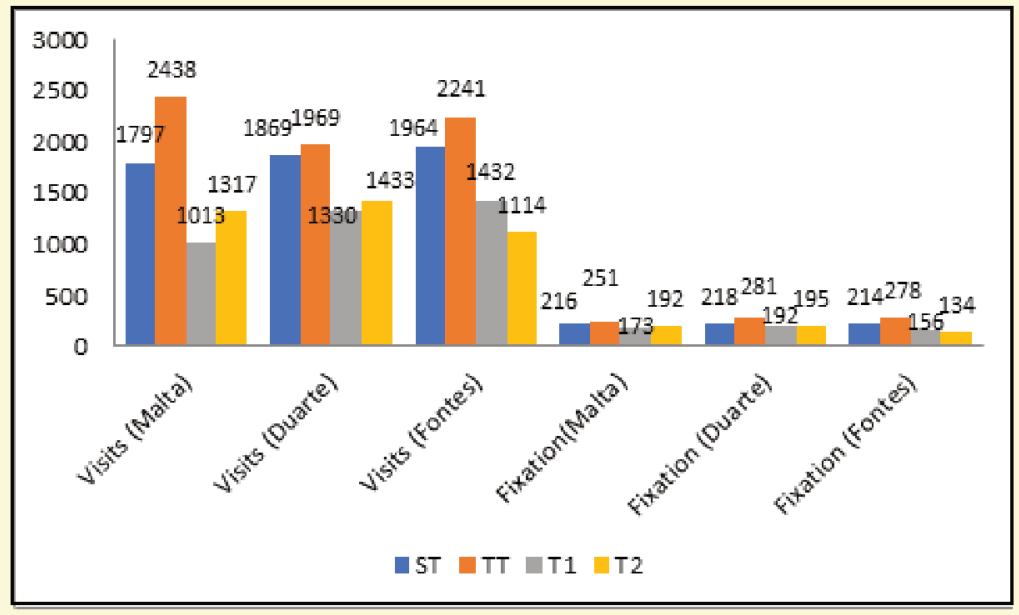

Figure 5 - Fixation duration mean and visit duration mean per area of interest (in milliseconds) in Malta, Duarte and Fontes.

Differences were also significant for visit duration. Malta hypothesises the several visits have different purposes, including understanding, revision, formulation, and problem solving. However, a pattern is seen in the three studies: visit and fixation durations are longer, in this order, in the TT, the ST and the previous translations.

Besides, the non-significant result for fixation duration in the T1-T2 combination is indicative of no cognitive effort to compare the previous translations in both Spanish-Portuguese and FrenchPortuguese language pairs. This result is also expected for Fontes in the English-Portuguese language pair, whose overall results have not been reported yet, and therefore were not included in Tables 4 and 5 . 


\begin{tabular}{|c|c|c|c|c|c|}
\hline \multirow{2}{*}{ Study } & \multirow{2}{*}{$\begin{array}{l}\text { Combi- } \\
\text { nations }\end{array}$} & \multicolumn{2}{|c|}{ VISIT DURATION } & \multicolumn{2}{|c|}{ FIXATION DURATION } \\
\hline & & Results & Relation & Results & Relation \\
\hline \multirow[t]{6}{*}{ Malta } & ST-T1 & $p=0.001094$ & $\mathrm{ST}>\mathrm{T} 1$ & $p=0.0002205$ & $\mathrm{ST}>\mathrm{T} 1$ \\
\hline & ST-T2 & $p=0.02191$ & $\mathrm{ST}>\mathrm{T} 2$ & $p=0.002326$ & $\mathrm{ST}>\mathrm{T} 2$ \\
\hline & TT-ST & $p=0.0003662$ & $\mathrm{TT}>\mathrm{ST}$ & $p=0.01605$ & $\mathrm{TT}>\mathrm{ST}$ \\
\hline & TT-T1 & $p=0.001184$ & $\mathrm{TT}>\mathrm{T} 1$ & $p=0.006776$ & $\mathrm{TT}>\mathrm{T} 1$ \\
\hline & TT-T2 & $p=0.0001093$ & $\mathrm{TT}>\mathrm{T} 2$ & $p=0.0001305$ & $\mathrm{TT}>\mathrm{T} 2$ \\
\hline & $\mathrm{T} 1-\mathrm{T} 2$ & $p=0.001184$ & $\mathrm{~T} 1<\mathrm{T} 2$ & $\begin{array}{l}p=0,15979 \\
(\mathrm{~ns})\end{array}$ & $\mathrm{T} 1<\mathrm{T} 2$ \\
\hline \multirow[t]{6}{*}{ Duarte } & ST-T1 & $p=0.003082$ & $\mathrm{ST}>\mathrm{T} 1$ & $p=0.002$ & $\mathrm{ST}>\mathrm{T} 1$ \\
\hline & ST-T2 & $p=0.02557$ & $\mathrm{ST}>\mathrm{T} 2$ & $p=0.005077$ & $\mathrm{ST}>\mathrm{T} 2$ \\
\hline & TT-ST & $p=0.5195(\mathrm{~ns})$ & $\mathrm{TT}>\mathrm{ST}$ & $p=0.01124$ & $\mathrm{TT}>\mathrm{ST}$ \\
\hline & TT-T1 & $p=0.03223$ & $\mathrm{TT}>\mathrm{T} 1$ & $p=0.0009766$ & $\mathrm{TT}>\mathrm{T} 1$ \\
\hline & TT-T2 & $p=0.06738(\mathrm{~ns})$ & $\mathrm{TT}>\mathrm{T} 2$ & $p=0.0009766$ & $\mathrm{TT}>\mathrm{T} 2$ \\
\hline & $\mathrm{T} 1-\mathrm{T} 2$ & $p=0.3604(\mathrm{~ns})$ & $\mathrm{T} 1<\mathrm{T} 2$ & $\begin{array}{l}p=0.4496 \\
(\mathrm{~ns})\end{array}$ & $\mathrm{T} 1<\mathrm{T} 2$ \\
\hline
\end{tabular}

Table 5 - Significance test results for visit and fixation durations in Malta and Duarte. Note: $n s=$ non-significance $(\mathrm{p}>0.05)$.

The participants' gaze in the four areas of interest provides a matrix of transitions across the ST, the TT and the previous translations (T1 and T2) in a (re)translation task. Table 6 shows one of such a matrix for Malta's study.

\begin{tabular}{lllll}
\hline & \multicolumn{1}{c}{$\rightarrow \mathrm{ST}$} & $\rightarrow \mathrm{TT}$ & $\rightarrow \mathrm{T} 1$ & $\rightarrow \mathrm{T} 2$ \\
\hline $\mathrm{ST} \rightarrow$ & - & 82.12 & 9.29 & 8.59 \\
$\mathrm{TT} \rightarrow$ & 67.11 & - & 17.25 & 15.64 \\
$\mathrm{~T} 1 \rightarrow$ & 30.18 & 48.78 & - & 21.04 \\
$\mathrm{~T} 2 \rightarrow$ & 23.94 & 55.67 & 20.39 & - \\
\hline
\end{tabular}

Table 6 - Percent matrix of transitions across ST, TT and previous translations (T1 and T2). Source: Malta (204).

The transition flow starts from reading the ST and then moving on to the TT in $82.12 \%$ of the cases. Transitions from the TT to 
the previous translations are more frequent than those from the ST (17.25 and $15.64 \%$ for T1 and T2, respectively), yet most of the transitions take place from the TT back to the ST. Transitions from the previous translations tend to occur to the TT (48.78 and $55.67 \%$ for $\mathrm{T} 1$ and $\mathrm{T} 2$, respectively).

Duarte does not provide a matrix of transition, but her transition percentages seem to resemble those of Malta: higher frequency of transitions in both ST-TT (27.4\%) and TT-ST directions (27.1\%).

In both Malta and Duarte, the TT serves as a link for information processing in a (re)translation task. Figure 6 shows a (re)translation process model that accounts for how information processing takes place in a (re)translation task. More specifically, it shows the gaze paths during such a task.

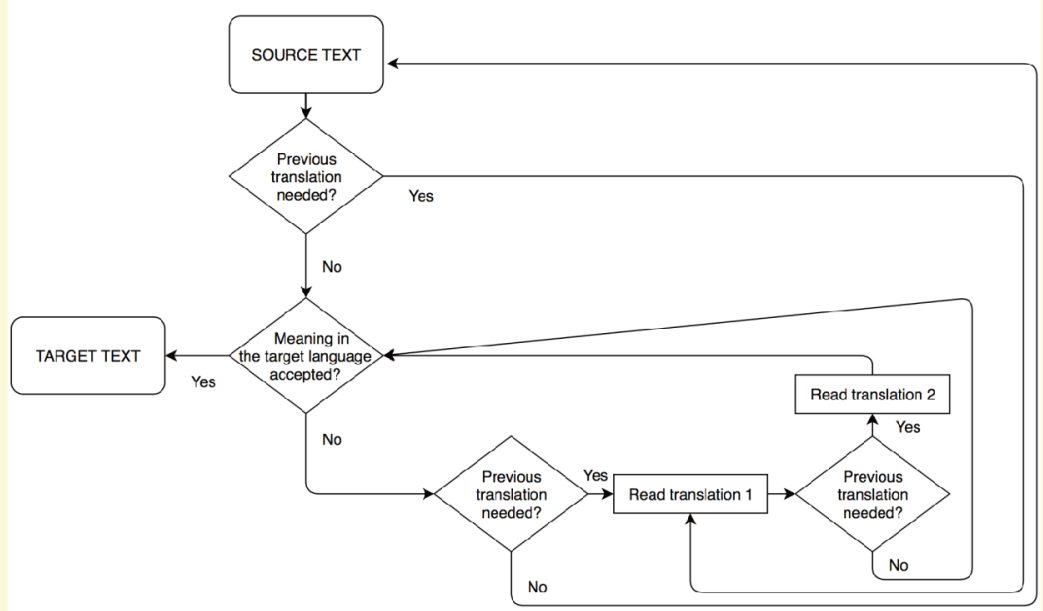

Figure 6 - (Re)translation process model.

Fonte: Adapted from Malta ("O processamento" 192).

According to the model (see Malta "O processamento", "O conceito" for further details), a participant may choose basically from two paths after facing the ST. One path is to look up for support in a previous translation to process, either partially or 
totally, the ST message. Another path is to translate the message and return to such previous translation to confirm or contrast the message the participant has just processed. Parallel to both paths is a less common path of gazing from one previous translation to another. In this case, the participant consults the solutions provided in order to opt for one of them, amalgamate them or even refuse them completely and then elaborate a translation of his/her own.

Two types of transitions were identified in considering such paths. Type 1, transitions for support to rendition, refers to transitions that depart from the ST toward a previous translation with a view to finding support in the processing of a message yet to be formulated in the target language. Type 2, transitions for confirmation/contrast, refers to transitions that depart from the TT toward a previous translation with a view to confirming the retranslator's rendition and/or contrasting it with the possibilities conveyed in the previous translations.

\section{Final remarks}

This paper reported on a set of three studies aimed to tap into (re)translation from a process-oriented perspective. The studies had an experimental nature, shared a similar experimental design, and addressed three different language pairs, with Brazilian Portuguese as their common target language. Their findings pointed to similar patterns in the execution of (re)translation tasks and provided the empirical basis for a (re)translation process model.

Such model accounts for a particular type of task whereby the translator is supposed to deal with more than one textual input. It shows that, despite the input of previous translations, the source text and the target text still play a major role in the participants' behaviour, regardless of their profile and the language pairs involved. In contrast, the previous translations play an ancillary role in the rendition of the new translation (the retranslation) 
by providing further understanding of the source text or new possibilities for renditions in the target text.

The proposal does not neglect the relevance of a product-based analysis, or better yet, the relevance of combining product-based and process-based methods to gain a better understanding of (re) translations. For instance, a product-based analysis may show that a participant came up with a very different solution from the previous translations, while a process-based analysis of eye-tracking data may show that a participant read the previous translations several times and his/her recall protocol may justify that his/her reason for doing so was that $\mathrm{s} /$ he wanted to be as creative as possible and provide a target text which did not resemble any previous translations in the target culture, which would be consistent with Venuti.

In fact, such factors as authorship and creativity may explain why translation process research has avoided using literary texts in experiments, as they have implications for measures of cognitive effort, such as pauses, recursiveness, and time (see Malta, "El concepto" for further details). While this might be an extra obstacle in relating the present results to previous research in the area, this is the very reason why literary texts should gain relevance. In the present study particularly, a brief asking the participants to (re) translate a previously translated text conceives of (re)translation as a task which is context-dependent. While the participants were not provided with the literary texts in their entirety, unlike participants in most translation process research their access to two previous translations granted them some knowledge of part of the source text's reception in the target culture. This access could guide them in their decision making or at least provide them with some food for thought as to what choices to make while coming up with a target text which may eventually be compared to or contrasted with previous translations by the target audience.

The results particularly contribute to studies on retranslation, since they represent a change in perspective from a productoriented to a process-oriented approach. They also contribute to the translation process research, as they account for a task that had not 
been explored yet, although a close task can be named: translation using translation memory systems (e.g., Bowker; Dragsted).

Nonetheless, the present results are exploratory to some extent: 1) they refer to literary texts, and therefore, are not fully comparable to results from most translation process research (see Table 1), and 2) the samples are small and incorporate different participant profiles and three languages pairs, with Brazilian Portuguese being the target language. Even though some statistical tests were used (especially because of the amount of data elicited through eye tracking), the results are not generalizable and serve the sole purpose of informing a model of (re)translation, which is now open for further tests, including for differences between students and professionals as well as for language pairs.

The final findings of Fonte's ongoing studies may add to results herein reported by shedding some light on other profiles (i.e., those of professional translators versus translation students) and providing data to refine the model proposed by Malta ("O processamento"). Furthermore, such experimental data as those collected to tap into the (re)translation may serve as a source of information for other branches of the translation studies, especially when it comes to the pedagogy of translation, which is still devoid of proposals based on empirical data. More specifically, the experiment itself used in this study, its results or its layout may be applied in the classroom as a way to raise students' awareness of what retranslation is, how different it is from plagiarism (Tarvi), how previous translations can be used to learn literary translation techniques, and how previous translations can support informed decision making. 


\section{References}

Almeida, Giselle, and Sharon O'Brien. "Analysing Post-Editing Performance: Correlations with Years of Translation Equivalence". European Association for Machine Translation. St Raphael, France: EAMT, 2010, pp. 1-8.

Alves, Fabio, Pagano, Adriana, and Igor Da Silva. "A New Window on Translators' Cognitive Activity: Methodological Issues in the Combined Use of Eye Tracking, Key Logging and Retrospective Protocols". Methodology, Technology and Innovation in Translation Process Research: A Tribute to Arnt Lykke Jakobsen. Ed. Inger Mees, Fabio Alves, and Susanne Göpferich. Copenhagen: Samfundslitteratur, 2009, pp. 267-292.

"Towards an Investigation of Reading Modalities in/for Translation". Cognitive Explorations of Translation. Ed. Sharon O'Brien. London: Continuum, 2011, pp. 175-191.

Austen, J. Emma. London: John Murray, 1815.

Austen, J. Emma. Transl. Ivo Barroso. Rio de janeiro: Nova Fronteira, 1996.

Austen, J. Emma. Transl. Doris Goettems. São Paulo: Landmark, 2011.

Bensimon, Paul. "Presentation”. Palimpsestes, vol. 4, 1990, pp. ix-xiii.

Berman, Antoine. "La Retraduction Comme Espace de Traduction". Palimpsestes, vol. 13, 1990, pp 1-7.

7Letras, 2007.

. A Tradução e a Letra ou O Albergue do Longínquo. Rio de Janeiro:

Bloom, Harold. The Anxiety of Influence: A Theory of Poetry. New York: Oxford University Press, 1973.

Bowker, Lynne. "Productivity vs Quality: A Pilot Study on the Impact of Translation Memory Systems". Localisation Focus, vol. 4, no. 1, 2005, pp. 13-20. 
Brownlie, Siobhan. "Narrative Theory and Retranslation Theory". Across Languages and Culture, vol. 7, 2006, pp. 140-170.

Brunette, Louise, Gagno, Chantal, and Hine Jonathan. "The GREVIS Project: Revise or Court Calamity". Across Languages and Cultures, vol. 6, no. 1, 2005, pp. 29-45.

Carl, Michael, and Barbara Dragsted. "Inside the Monitor Model: Processes of Default and Challenged Translation Production". Translation: Computation, Corpora, Cognition, vol. 2, no. 1, 2005, pp. 127-145.

Chesterman, Andrew. "A Casual Model for Translation Studies”. Intercultural Faultlines. Ed. Maeve Olohan. Manchester: St. Jerome, 2000, pp. 15-27.

Cortázar, J. “Casa tomada”. Revista Los Anales de Buenos Aires, 1946.

. "A casa tomada". (Org. e Trad.). Contos latino-americanos eternos. Org. and transl. Alicia Ramal. Rio de Janeiro: Bom Texto Editora, 2005, pp. 7-9.

. “Casa tomada". A autoestrada do sul e outras histórias. Org. Sérgio Karam. Transl. Heloisa Jahn. São Paulo: L\&PM Pocket, 2013, pp. 33-39.

Da Silva, Igor. (Des)compactação de Significados e Esforço Cognitivo no Processo Tradutório: Um Estudo da Metáfora Gramatical na Construção do Texto Traduzido. Doctoral dissertation, Belo Horizonte: FALE- UFMG, 2012.

Da Silva, Igor, Braga, Camila, and Maria Luísa de Oliveira. "Corpora de Pequenas Dimensões na Análise do Conhecimento Experto em Tradução: Um Estudo de Caso". Textos e Leituras: Estudos Empíricos de Língua e Literatura. Ed. Sonia Zyngier, Vander Viana, and Juliana Jandre. Rio de Janeiro: Publit, 2007, pp. 105-122.

Dastjerdi, Hossein V., and Amene Mohammadi. "Revisiting 'Retranslation Hypothesis': A Comparative Analysis of Stylistic Features in the Persian Retranslations of Pride and Prejudice". Open Journal of Modern Linguistics, vol. 3, no. 3, 2013, pp. 174-181.

Deane-Cox, Sharon. Retranslation: Translation, Literature and Reinterpretation. London: Bloomsbury, 2014. 
Desmidt, Isabelle. “(Re)translation Revisited”. Meta: Journal des Traducteurs, vol. 54, no. 4, 2009, pp. 669-683.

Dragsted, Barbara. Segmentation in Translation and Translation Memory Systems: An Empirical Investigation of Cognitive Segmentation and Effects of Integrating a TM System into the Translation Process. Doctoral dissertation, Copenhagen Business School: Samfundslitteratur, 2004.

Duarte, Luana M. Alocação de Esforço Cognitivo em uma Tarefa de (Re) tradução: Estudo Sobre Desempenho no Par Linguístico Francês-Português. Master's thesis, Faculdade de Letras, Universidade Federal de Minas Gerais, Belo Horizonte, 2017.

Duras, M. L'amant. Paris: Editions de Minuit, c1984.

. O amante. Transl. Denise Bottmann. São Paulo: Cosac; Naify, 2007.

. O amante. Transl. Aulyde Soares Rodrigues. Rio de Janeiro: Nova Fronteira, 1985.

Fontes, Cristiane. O processo tradutório em tarefas de (re)tradução: um estudo no par linguístico inglês-português. Doctoral project, Belo Horizonte: FALEUFMG, ongoing.

Gambier, Yves. "La Retraduction, Retour et Tour". Meta: Journal des Traducteurs, vol. 39, 1994, pp. 413-417.

Hvelplund, Kristian T. Allocation of Cognitive Resources in Translation: An EyeTracking and Key-Logging Study. Doctoral dissertation, Copenhagen Business School, 2011, pp. 260.

. "Eye Tracking and the Translation Process: Reflections on the Analysis and Interpretation of Eye-Tracking Data". MonTI, Special Issue - Minding Translation, 2014, pp. 201-223.

. "Eye Tracking and the Process of Dubbing Translation". FastForwarding with Audiovisual Translation. Ed. Jorge Díaz-Cintas, and Kristijan Nikolić. Bristol: Multilingual Matters, 2017. 
Jakobsen, Arnt L. "Logging Target Text Production with Translog". Probing the Process in Translation: Methods and Results. Ed. Gyde Hansen. Copenhagen: Samfundslitteratur, 1999, pp. 9-20.

Jakobsen, Arnt L., and Kristian T. Jensen. "Eye Movement Behavior". Copenhagen Studies in Language, vol. 36, 2008, pp. 103-124.

Just, Marcel A., and Carpenter, Patricia. "A Theory of Reading: From Eye Fixations to Comprehension”. Psychological Review, vol. 85, 1980, pp. 109-130.

Koglin, Arlene. Efeitos Cognitivos e Esforço de Processamento de Metáforas em Tarefas de Pós-Edição e de Tradução Humana: Uma Investigação Processual à Luz da Teoria da Relevância. Doctoral dissertation, Belo Horizonte: FALEUFMG, 2015.

Krings, Hans P. Repairing Texts: Empirical Investigations of Machine Translation Post-Editing Processes. Kent State University Press: Kent/Ohio, 2001.

Künzli, Alexander. "The Ethical Dimension of Translation Revision. An Empirical Study”. The Journal of Specialised Translation, vol. 8, 2007, pp. 42-56.

Malta, Gleiton. O Processamento Cognitivo em Tarefas de (Re)tradução: Um Estudo Baseado em Rastreamento Ocular, Registro de Teclado e Mouse e Protocolos Verbais. Doctoral dissertation, Belo Horizonte: FALE- UFMG, 2015.

. "O Conceito de (Re)tradução sob uma Abordagem Processual: Um Estudo Empírico-Experimental Baseado em Rastreamento Ocular”. Letras e Letras, vol. 32, no. 1, 2016, pp. 283-305.

. "El Concepto de (Re)Traducción bajo el Abordaje Procesual: Un Estudio Empírico-Experimental Basado en Datos de Registro de Teclado y Ratón". Mutatis Mutandis, vol. 10(2), 2017, pp. 195-228.

Malta, Gleiton, and Elaine Rael. "As retraduções de La Casa de Los Espíritus: Uma (Re)visita à Hipótese da Retradução". Revista Letras Raras, vol. 4, no. 3, 2015, pp. 75-97.

Malta, Gleiton, and Luciana Cristina Silva dos Reis. "A Retradução de Advérbios Terminados em -mente: Um Estudo Baseado em um Corpus Literário no Par 
Linguístico Espanhol-Português”. Revista Belas Infieis, vol. 6, no. 1, 2017, pp. 75-85.

Mesa Lao, Bartolomé. "Gaze Behaviour on Source Texts: An Exploratory Study Comparing Translation and Post-Editing". Post-editing of Machine Translation: Processes and Applications. Ed. Sharon O'Brien, Laura Winther Balling, Michael Carl, Michel Simard, and Lucia Specia. Newcastle upon Tyne: Cambridge Scholars Publishing, 2014.

Mossop, Brian. "Empirical Studies of Revision: What We Know and Need to Know”. The Journal of Specialised Translation, vol. 8, 2007, pp. 5-20.

O’Brien, Sharon. "Eye Tracking in Translation Process Research: Methodological Challenges and Solutions". Methodology, Technology and Innovation in Translation Process Research: A Tribute to Arnt Lykke Jakobsen. Ed. Inger Mees, Fabio Alves, and Susanne Göpferich. Copenhagen: Samfundslitteratur, 2009, pp. 251-266.

O'Brien, Sharon, Balling, Laura W., Carl, Michael, Simard, Michael, and Lucia Specia. Post-editing of Machine Translation: Processes and Applications. Newcastle: Cambridge Scholars Publishing, 2014.

Pagano, Adriana, and Cristiano G. Araújo. “(Des)metaforizando significados na Pós-Edição: Um Estudo Exploratório de Esforço Despendido por Estudantes de Tradução". Revista de Estudos da Linguagem, vol. 21, 2013, pp. 97-127.

Paloposki, Outi, and Kaisa Koskinen. "Reprocessing Texts: The Fine Line Between Retranslating and Revising". Across Languages and Cultures, vol. 11, no. 1, 2010, pp. 29-49.

Pavlovic, Nataša, and Kristian T. Jensen. "Eye-Tracking Translation Directionality". Translation Research Projects 2. Ed. Antony Pym, and Alexander Perekrestenko. Tarragona: Intercultural Studies Group, 2009, pp 93-109.

Pym, Antony. Method in Translation History. Manchester: St. Jeronime, 1998.

Rainer, Keith. Eye Movements in Reading and Information Processing: 20 Years of Research. Psychological Bulletin, vol. 124, 1998, pp. 372-422. 
Rainer, Keith, and Alexander Pollatzec. The Psychology of Reading. Englewood Cliffs, N.J.: Prentice-Hall, 1989.

Robert, Isabelle. "Translation Revision Procedures: An Explorative Study". Translation and Its Others. Ed. Pieter Boulogne. Leuven: KU Leuven, 2008, pp. 1-25.

Rodrigues, Cássio A. “Abordagem Processual no Estudo da Tradução: Uma Meta-Análise Qualitativa”. Cadernos de Tradução, vol. 2, no. 10.

Sekino, Kyoko. Investigando Processos de Pós-Edição e de Tradução: Uma Análise Cognitivo-Pragmática da Relação Esforço-Efeito no par Linguístico Japonês-Português. Doctoral dissertation, Belo Horizonte: FALE- UFMG, 2015.

Susam-Sarajeva, Susan. "Multiple Visa to Travelling Theory: Retranslation of Literary and Cultural Theories". Target, International Journal of Translations studies, vol. 15, no. 1, 2014, pp. 1-36.

Tahir-Gürçalar, Sehnaz. "Retranslation". Routledge Encyclopaedia of Translation Studies. Ed. Mona Baker, and Kirsten Malmkjaer. London: Routledge, 1998, pp. 125-127.

Tarvi, L. "The Problems of Managing the 'Translation Stock': Freelancing vs. Freebooting”. Ethics and Politics of Translation. Ed. Meike Reintjes, and Marie Tåqvist. Norwich: University of East Anglia, 2005, pp. 125-140.

Venuti, Lawrence. "Retranslations: The Creation of Value". Bucknell Review, vol. 47, no. 1, 2004, pp. 25-38.

Recebido em: 24/08/2018

Aceito em: 19/11/2018

Publicado em janeiro de 2019

Cristiane Silva Fontes. E-mail: cristiane.fontes@ifmg.edu.br

ORCID: https://orcid.org/0000-0003-0506-5826

Gleiton Malta. E-mail: gleitonmalta@gmail.com, maltaunb@unb.br ORCID: https://orcid.org/0000-0003-0359-4046.

Igor Antônio Lourenço da Silva. E-mail: ials@ufu.br, ialsigor@gmail.com. ORCID: https://orcid.org/0000-0003-0738-3262 